\title{
The effect of online service quality and consumers' motivation on willingness to participate in co-creation activities
}

\author{
Agnes Gracia Quita ${ }^{1 *}$, Sahid Susilo Nugroho ${ }^{2}$ \\ Fakultas Bisnis dan Ekonomika, Universitas Atma Jaya Yogyakarta \\ Fakultas Ekonomika Dan Bisnis, Universitas Gadjah Mada \\ ${ }^{*}$ Corresponding author: agnesgraciaquita@gmail.com
}

\begin{abstract}
This study examines factors that encourage consumers to participate in co-creation activities. There are two factors that have been tested concerning their roles in determining the willingness of consumers to participate in co-creation activities. The first factor comprise the system and techonology of the service provider. Those are reflected in availability, privacy, and responsiveness aspects of the e-service quality. The second factor is consumer behavior. It is reflected in social motivation and financial motivation aspects. This study applied a survey method using a purposive sampling method to interview 303 respondents. Data were obtained through an online survey. The proposed hypotheses are tested using multiple regression analyses. The study finds that availability, responsiveness, and social motivation have positive impacts on the willingness of consumers to participate in co-creation activities. Conversely, privacy and financial motivation have no effect at all.
\end{abstract}

Keywords: e-service quality, motivation, co-creation

\begin{tabular}{ll}
\hline JEL Classification Code: M11, M31, M39 DOI: 10.20885/jsb.vol23.iss2.art4 & D.
\end{tabular}

\section{Introduction}

Digitalisation in the business sector bring out an increasing, stringent and fast industrial rhythm and competition (Veit et al., 2014). One of the company's efforts to improve the quality of its services is through a collaborative approach with consumers well-known as co-creation strategy. In this approach, the role of consumers changes from the recipient of the company's services and products, shifting into a business partner that contributes to the development of better products and services (Tapscott \& William, 2006). Intensive interaction between companies and consumers in the cocreation process will be a superior information resource for the company (Robert et al., 2014).

A number of pioneering companies that already implemented co-creation strategy shown that the co-creation paradigm is a process of integrating the role of consumers into the company's production process. Consumers as direct users of products will also invest time, ideas and energy, and even funds to participate in development process to meet the better products and services (Ernts et al., 2010). The co-creation strategy is believed as a tools that enable to simplify the flow of conventional business processes. For instance, bussiness processes usually start from market survey activities to understand the needs and wants of the existing market, however, the survey results may not easy to be interpreted. Using co-creation, consumer involvement in the process of surveying market needs, will reduce such uncertainty. Considering the extraordinary benefits of co-creation activities, companies need to improve the quality of relationships with consumers to get more optimal consumer participation in creative program to ensure the marketing success (Ramaswamy, 2009; Wu, 2011).

The proof of the successful program of co-creative system between companies and consumers can be found in the "The 500 Want You" program organized by the Fiat automotive company in 2007 (Filieri \& Alguezavi, 2012). Fiat launches a Fiat 500 car with a retro style design. The whole process of developing this new car generation has involved consumers from the beginning, namely in the process of ideation (generating idea form consumer) through the interaction process on the Fiat page 
(website). Moreover, the co-creation program successfully influences Fiat launching stage. Fiat managed to sell 57 thousands of the cars in the first month (i.e. July 2007) after its launching (Filieri and Alguezavi, 2012). Many marketing experts consider the process of developing Fiat 500 to be one of the most perfect successful the co-creation example, and it still an icon of the uniqueness and technological advancement case.

Building relationships with consumers as business partners, can not necessarily be done if the company and consumers do not build a mutually beneficial relationship (Nambisan, 2002). As a consequence, companies need to examine what factors that encourage consumers to participate in a co-creation program (O'Pappas et al., 2014). In this study, these factors are investigated and divided into two categories. First, the systems and technology categories from enterprise. It examines services provider web or app refer to aspects of availability, privacy and responsiveness to the quality of online services. Second, the category of consumer behavior, consisting of social motivation aspect and financial motivation aspect.

This study modified research model developed in previous studies such as Elsharnouby \& Mahrous (2015) and Fernandes \& Remelhe (2016). The first research model, Elsharnouby \& Mahrous (2015) examine the influence of online service quality dimensions, namely efficiency, availability, fulfillment, privacy, responsiveness, compensation, and contact on consumers' willingness to make co-creations. The second research model, Fernandes \& Remelhe (2016), examine the effect of various motivations, namely intrinsic motivation, knowledge motivation, social motivation, and financial motivation on consumers' willingness to perform co-creations.

The study model uses three dimensions of online service quality such as availability, privacy, and responsiveness which are considered to influence consumers' willingness to participate in cocreative activities. Although previous studies investigated these dimensions, findings from previous studies still inconsistent or inconclusive (Elshanourby \& Mahrous, 2015; Basoglu et al., 2014; Loureiro, 2015; Carlson \& O'Cass, 2010; Sheng \& Liu, 2010; Elliot \& Speck, 2005; Wolfinbarger \& Gilly, 2003). This study is expected to complete the understanding of co-creation from the view of young consumers comprehensively. The second part of the study model is two dimensions of consumer behaviour that is believed having impact on consumers' willingness to participate in joint creative activities namely social motivation and financial motivation. Findings related to the two dimensions from previous studies also show inconsistent results (Fernandes \& Remelhe, 2016; Wirtz et al., 2013; Frey et al., 2011; Füller, 2006). Hence, findings from the second part of the model is expected adding comprehensive view of young consumer motivation that is assumed to be different from its predecessor generation.

Although previous studies on joint creative activities like co-creation has been carried out, in the Indonesia context, most of the studies tedn to examine the process of collaboration in the stages of production. This study is differed compared to the previous studies since this study focuses on antecedents or predictors of consumers' willingness to participate in co-creation activities based on two main perspectives. The first perspective is the perspective of customer satisfaction with the quality of the company's online services. In this first perspective, indicators used are website or application readiness, security in online transactions and also online responsiveness. While the second perspective is consumer attitude, it is not from the company but from the consumers point of view. This study examines two main factors in human motivation when making decision. The first major factor is consideration of material profit or financial motivation, whilst the second factor is social benefits or social motivation. Therefore, this study model is expected to complete the understanding of cocreation studies more comprehensively.

This study focuses on young consumers (born between 1980 - 2000; millennials, and early z generation) in online service businesses. Young consumers are involved in this study due to several reasons. First, young consumers are the largest population now, and proven as a segment with high purchasing power. The millennial generation until today represents 50 percent of total global consumption in 2017 (Orozpe, 2014). Second, millennial generation consumers are closely related to 
the high level of technology adoption in everyday life (Moreno et al., 2017). Third, millennials are consumers who have a high level of enthusiasm in the concept of co-creation (Orozpe, 2014).

\section{Literature Review}

\section{Consumers Willingness to Participate in Co-Creations}

Basically the process of co-creation between the company and consumers have implications for the costs and the benefits received by consumers. The planned behavior theory conceptually explains the process of the relationship between consumer motivation factors and consumers' willingness to engage in joint creative activities. Consumers will rationalize the proposition to participate in joint creative activities by comparing the costs and benefits derived from these activities (Hoyer et al., 2010). Consumers will involve voluntarily if consumers consider that co-creation activities provide the possibility of benefits or not detrimental them (Füller, 2010).

The company's readiness to carry out co-creation activities is also measured based on consumers' assessment of the quality of the company's online services. Barrutia and Gilsanz (2013) suggest that positive consumer perceptions on the value of convenience and usability value in the company's online service system are believed shape positive attitudes and consumer behavior towards the company. The technology acceptance model (TAM) theory conceptually explains the reasons for consumers 'willingness to participate in co-creation activities will also be interpreted based on consumers' assessments of the quality of online services over aspects concerning convenience and utility value. Consumer acceptance in technology is further reflected in positive consumer ratings of the quality of the company's online services. Especially from the technological aspect that is termed as "the service that functions" and "the service that easy to use".

Prahalad \& Ramaswamy (2004) define co-creation as a strategy that considers the market as a forum for companies and consumers to create value through various forms of interaction, service mechanisms, and learning. While Vargo \& Lusch (2008) define co-creation as a dynamic interaction in the form of consumer engagement with companies at each stage of the value creation process.

Optimal degree of consumers involvement in co-creation activities is viewed based on positive consumer attitudes, that can be seen through the form of enthusiasm, dedication, and absorption within program. The enthusiasm is characterized by the sincerity of consumers to invest the best ability and perseverance in co-creation activities. Dedication is demonstrated through a sense of belonging and enthusiasm to engage in co-creation activities. Absorption is described as a phase in which consumers are fully concentrated on the co-creation activities that are being undertaken.

In this study, willingness to participate in co-creations is defined as intention of consumers to participate in activities by carried out constructive input for improvement, ideas and cooperation or collaboration (Elsharnouby \& Mahrous, 2015). Co-creation can also provide different psychological benefits to participants in its activities. For example the opportunity to work and improve various competencies. These advantages and benefits influence consumers to highly participate in the program (Heish \& Chang, 2016).

\section{Online Service Quality for Consumers' Participation in Co-Creation}

The construct of online service quality in this study refers to the study of Parasuraman et al., (2005). This constructs have been widely used by previous studies (Yen and Lu, 2008), which include some topics such as entire consumer shopping experience that consists of availability, responsiveness, and privacy (Basoglu et al., 2014; Carlson \& O'Cass, 2010; Elsharnouby \& Mahrous, 2015; Gera, 2011; Loureiro, 2015; Sheng \& Liu, 2010; and Van Noort et al., 2008).

Availability is defined as a consumer's assessment of the reliability of the page and application in the consistency of service delivery from time to time. Privacy is a consumer's assessment of the reliability of the page and the application in protecting consumers' personal information. Responsiveness is defined as the consumer's assessment of the reliability of the page as well as the 
application in managing the consumer's online shopping process. That includes handling the process of returning goods that are not appropriate, and delivering fast feedback when consumers need information in the online shopping process (Kim \& Kim 2010).

The experience of co-creation is very dependent or strongly related to co-creation environment characteristics. These characteristics include the existence of supporting technology such as attributes in online devices that can help smooth the process of interaction (Verleye, 2015). Good technical features will trigger an impetus for service users to work more intensively in applications and pages (Wolfinbarger \& Gilly, 2003). Due to these prepositions it is assume that when consumers realize that the company has provided an adequate technical service system, consumers will increase the desire to engage further into co-creation activities (Zhang \& Chen, 2008). Hence, a hypothesis related the availability of online service quality can be proposed:

H1: Availability in the quality of online services positively effects customers' willingness to participate in co-creation activities

Yang \& Fang (2004) find that consumers hesitate to re-visit online stores, when they feel that their shopping activities are not safe. Consumers doubt also occurs if they feel that the financial risks arise when they are purchasing (Korgaonkar \& Karson, 2007). The reputation of online store security is an important factor in online shopping context (Mahrous, 2011). Trust is very important in online activities because consumers tent to avoid risk. Hence it is important for companies to reduce perceived risks and strengthen relationships with consumers through privacy assurance (Elsharnouby \& Parsons, 2010; 2013). The relationship between consumers and the co-creation providers will be better if consumers realize that the services providers have guaranteed the protection of their personal data. Based on that fact, pages or applications that have a good protection system will increase the desire of consumers to engage in co-creation activities. Consumers' willingness to participate in cocreation activities will increase when they have confidence that all information related to activities carried out with the company will not be misused by the company or other third parties such as hackers (Santos, 2003). Therefore, a hypothesis related to privacy of online service quality can be proposed:

H2: Privacy in the quality of online services has a positive effect on consumers' willingness to participate in co-creation activities

Responsiveness is the company's capability to assist consumers in the course of transactions, it is defined when the site or app of the company demonstrated the responsiveness of services, especially when consumers have a problem (Kim et al., 2006). Responsiveness can be shown from the level of interaction and responsibility from online services. Responsiveness has a significant effect towards active participation that can be observed from the level of contribution and duration from participants during the co-creation activities. (Chen et al., 2011).

Implementing a system with the right technology supports the speed of feedback. Not all consumers look for relational interactions throughout the meetings with service providers (Elsharnouby \& Parsons, 2010), some consumers are interested in utilitarian interactions. In this condition it can be interpreted that some customers prefer to interact with the technical system than customer service. Consequently, the service attribute functionality is a determinant that shapes consumer attitudes towards the website page. Previous studies have shown that responsiveness affects consumers assessments of service quality and also with customer satisfaction (Lee \& Lin, 2005; Yang \& Fang, 2004). When service attributes interact well with consumer problems, consumers will be more interested in participating with other activities offered by companies, for instance co-creations program (Yang \& Jun, 2002). Practically, consumers will have a positive perception when they feel the responsiveness of a good company. So consumers will be more willing to participate in cocreations. 
H3: Responsiveness in the quality of online services has a positive effect towards the willingness of customer participation in co-creation activities

\section{Consumer Motivation for Consumer Willingness to Participate in Creative Creation}

Although empirical evidence regarding the influence of intrinsic and extrinsic motivational elements still shows relativity in certain consumer behavioral contexts, most motivational studies find that the components of intrinsic and extrinsic motivation are the two most important elements in predicting consumer behavior (Krishnamurthy, 2006). Consumer motivation in co-creation activities changes the direction of common motivation, which it's supposed to be generally centered on the individual ego, turns into motivation towards the community or activity that is followed (Fuller, 2006).

Etgar (2008) identifies two categories of the benefits of co-creation activities expected by consumers, namely financial benefits and social benefits. Social motivation refer to social benefits that consist of opportunities to have preferable social relations, status, and social rewards. Etgar (2008) concludes that customer participation in co-creation activities provides social value for the customer concerned. The intended social value consist within the form of opportunities to connect with people who have similar thoughts and self-efficacy (Holbrook, 2006). The opportunity to form a community in joint creative activities will also encourage customers to participate in joint creative activities (Achrol \& Kotler, 2006).

H4: Social motivation has a positive effect on the willingness of customers to participate in cocreation activities

Customers expect that through co-creation activities there are economic benefits that can be obtained (Nambisan, 2009). These economic benefits can be in the form of special prices or other privileges given only to participants in these activities (Holbrook, 2006). Consumers will take part in joint creative activities if they know they will get benefits in the future (Gabauer et al., 2013).

H5: Financial motivation has a positive effect on consumers' willingness to participate in co-creation activities

\section{Research Model}

The complete research model consists of six variables including one dependent variable, the willingness of consumer participation in co-creation as the consequence variable, and five antecedentvariables namely availability, privacy, responsiveness, social motivation, and financial motivation. The five independent variables together have a positive influence on the dependent variable as shown in Figure 1.

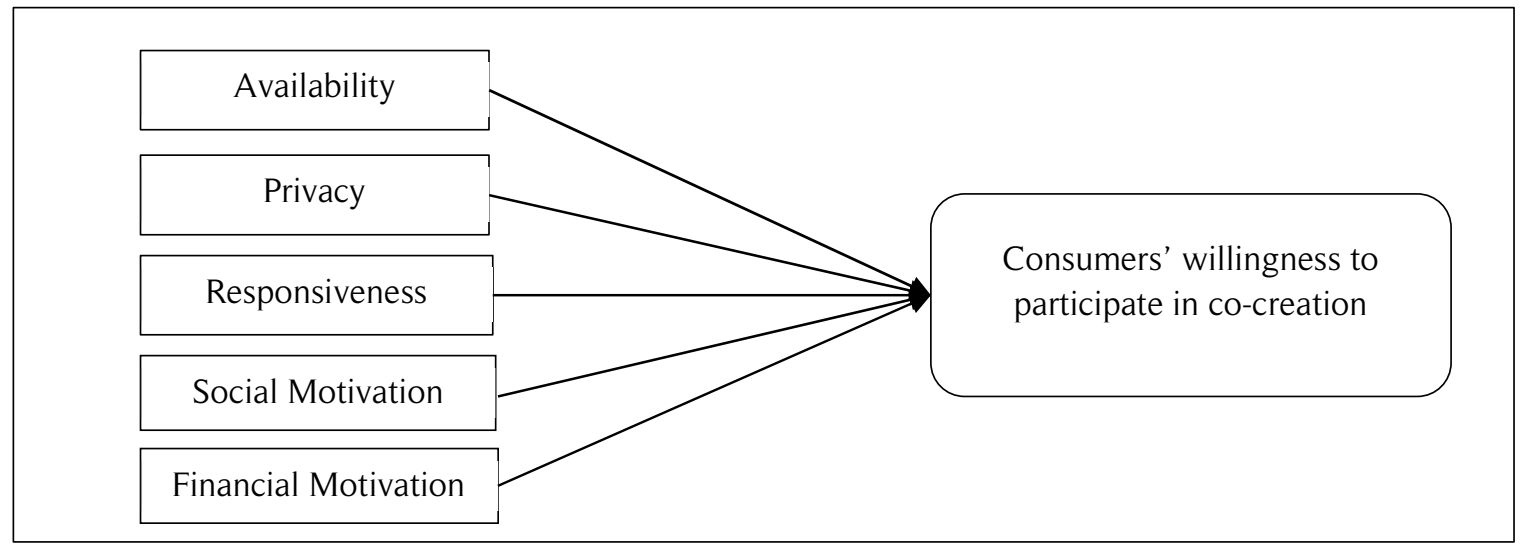

Source: Elsharnouby \& Mahrous (2015), Fernandes \& Remelhe (2016)

Figure 1. Research Model 


\section{Methods}

This study uses quantitative method with cross-sectional approach. Questionnaires are employed to collect data. The total number of questions in the questionnaire is 24 and Likert scale is used to measure the respondents' responses. The sampling technique is non-probability approach using purposive sampling method.

This study chooses company service businesses with some main categories as the research object. The first requirement is the company using only online platform as the sole medium of doing business (online pages and applications, especially those that provide facilities to interact with consumers). The second character is all objects of the research represent the character of young consumer lifestyle today. Young consumer consumption is aimed to create status and personality (Francis et al., 2015). Therefore, the chosen object is service business that symbolizes uniqueness, flexibility and technology (related to millennial/youngers preference). Based on these reasons this study focuses on Go-Jek, Traveloka and Adorable Project as its objects.

The sample unit criteria are active customers of Go-Jek, Traveloka and Adorable Project in the past 6 months. The sample size in this study was 303 respondents who live in various regions such as Java, Sumatra, Kalimantan, Pula, Nusa Tenggara, Pulasi Bali, Sulawesi and Papua. Figure 2 presents a wide range of respondents' location. Most respondents in this study are young generation (millennials) who were born between 1980 to 2000. In terms of gender, women outnumbered men i.e. 170 people (56.4 percent), and most of them are students i.e. 201 people (66.3 percent).

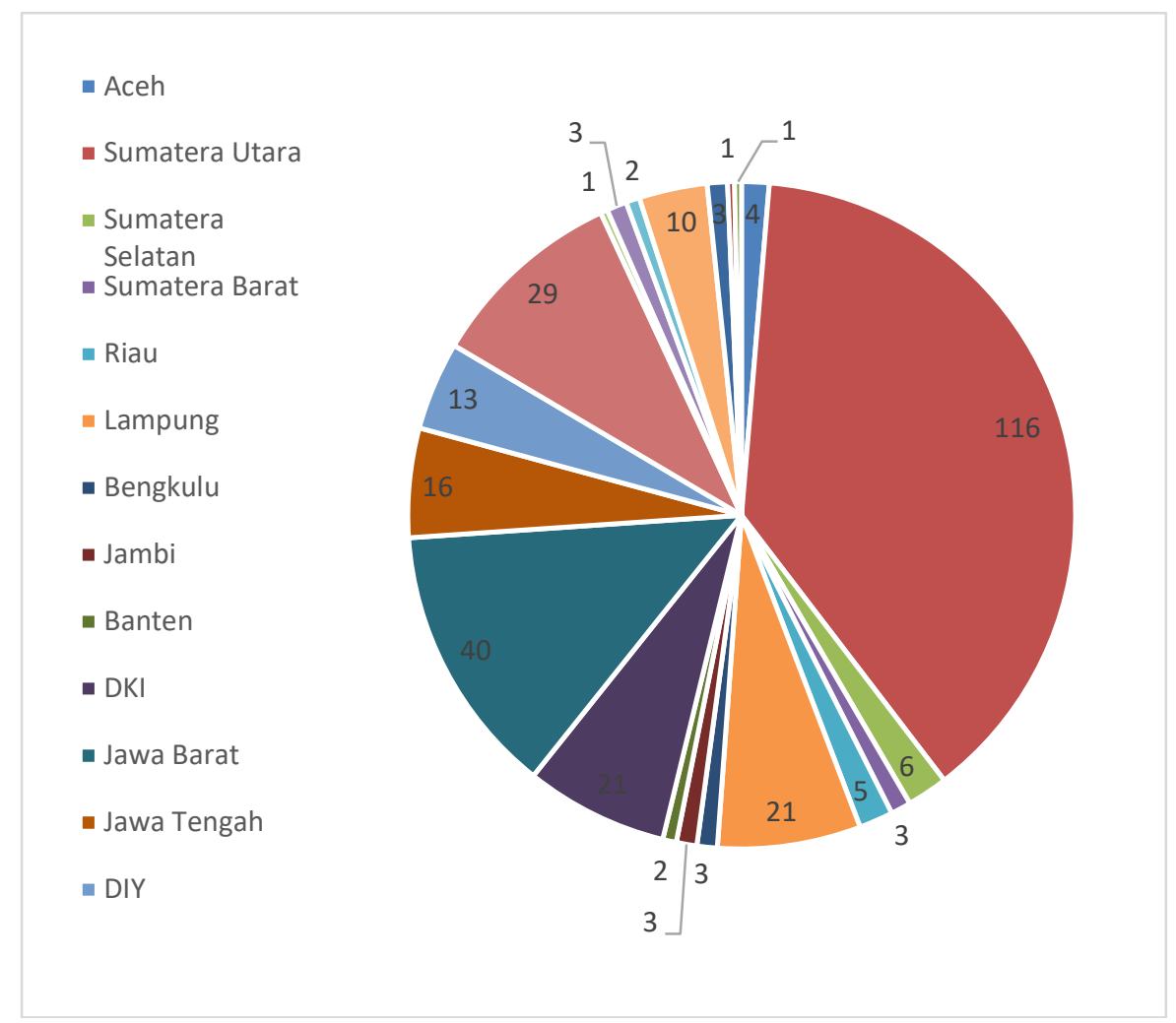

Source: Primary Data (2018)

Figure 2. Research Location Distribution

Table 1 presents the validity and reliability test results. Factor analysis shows a KMO value of .863 and a significant Bartlet test value. All items have factor loading values above 0.5 and each item successfully groups according to the similarity of the measured variables. Hence, it can be concluded that 24 questions are valid and can be used for further analysis. Furthermore, in reliability testing, all 
measurement items in each variable have a Cronbach's Aplha value above 0.6 which means that all items are reliable.

Table 1. Validity and Reliability Testing Results

\begin{tabular}{|c|c|c|c|c|c|c|c|c|c|c|}
\hline \multirow{2}{*}{ VARIABEL } & \multirow{2}{*}{ ITEMS } & \multicolumn{6}{|c|}{ FACTORS } & \multirow{2}{*}{$\begin{array}{l}\text { AVERAGE } \\
\text { VALUE }\end{array}$} & \multirow{2}{*}{$\begin{array}{l}\text { DEVIATION } \\
\text { STANDARDS }\end{array}$} & \multirow{2}{*}{$\begin{array}{c}\text { CRONBACH } \\
\text { ALPHA }\end{array}$} \\
\hline & & 1 & 2 & 3 & 4 & 5 & 6 & & & \\
\hline \multirow{4}{*}{ Availability } & K1 & & & & .534 & & & \multirow{4}{*}{3.98} & \multirow{4}{*}{.554} & \multirow{4}{*}{.752} \\
\hline & $\mathrm{K} 2$ & & & & .641 & & & & & \\
\hline & K3 & & & & .792 & & & & & \\
\hline & K4 & & & & .785 & & & & & \\
\hline \multirow{3}{*}{ Privacy } & P1 & & & & & .781 & & \multirow{3}{*}{3.79} & \multirow{3}{*}{.637} & \multirow{3}{*}{.791} \\
\hline & P2 & & & & & .832 & & & & \\
\hline & P3 & & & & & .767 & & & & \\
\hline \multirow{5}{*}{ Responsiveness } & DT1 & & & .719 & & & & \multirow{5}{*}{3.86} & \multirow{5}{*}{.594} & \multirow{5}{*}{.814} \\
\hline & DT2 & & & .806 & & & & & & \\
\hline & DT3 & & & .658 & & & & & & \\
\hline & DT4 & & & .601 & & & & & & \\
\hline & DT5 & & & .705 & & & & & & \\
\hline \multirow{4}{*}{$\begin{array}{l}\text { Social } \\
\text { Motivation }\end{array}$} & MS1 & & .783 & & & & & \multirow{4}{*}{3.33} & \multirow{4}{*}{.653} & \multirow{4}{*}{.858} \\
\hline & MS2 & & .828 & & & & & & & \\
\hline & MS3 & & .692 & & & & & & & \\
\hline & MS4 & & .781 & & & & & & & \\
\hline \multirow{2}{*}{$\begin{array}{l}\text { Financial } \\
\text { Motivation }\end{array}$} & MF1 & & & & & & .757 & \multirow{2}{*}{3.42} & \multirow{2}{*}{.801} & \multirow{2}{*}{.772} \\
\hline & MF2 & & & & & & .739 & & & \\
\hline \multirow{6}{*}{$\begin{array}{l}\text { Customer } \\
\text { Participation in } \\
\text { Joint Creative } \\
\text { Activities }\end{array}$} & KB1 & .734 & & & & & & \multirow{6}{*}{3.77} & \multirow{6}{*}{.537} & \multirow{6}{*}{.819} \\
\hline & KB2 & .800 & & & & & & & & \\
\hline & KB3 & .608 & & & & & & & & \\
\hline & KB4 & .737 & & & & & & & & \\
\hline & KB5 & .639 & & & & & & & & \\
\hline & KB6 & .544 & & & & & & & & \\
\hline
\end{tabular}

Source: Primary Data (2018)

\section{Results and Discussion}

Table 2 displays multiple regression results to test the proposed hypotheses. The first hypothesis is supported (beta value is .199 and significance value is .000). This means that availability has a positive effect on the willingness of customer to participate in co-creations. This finding is different compared to previous study e.g. Elshnourby \& Malharous (2015), but it in line with studies conducted by Zhang and Chen (2008) and Varleye (2014). The finding indicates that consumers who feel technical and system reliability will show interest in participating a co-creation program. Further analysis also can be concluded i.e. consumers who are familiar with computers and the internet are most customers who are motivated to engage in a co-creation program.

The second hypothesis is not supported (beta value is -.022 and significance is .683). The result shows an opposite finding, privacy actually has a negative effect and has no significant impact on customers' willingness to participate in a co-creation program. Differences in research context to be one of the reasons privacy in online service quality does not affect consumers' willingness to 
participate in co-creation activities. Today's consumer confidence is not only based on the reputation of online service providers, but also based on their own ability, because young consumers have better mastery of technology (Schooley et al., 2005). Furthermore, consumer confidence is also influenced by the third party systems which able to maintain privacy more structurally, namely systems that include official security networks from the government, security guarantees from service providers, and regulations that promote data privacy security (Alton, 2017; Montazemi \& Saremi, 2015).

Table 2. Hypothesis Testing Results

\begin{tabular}{|c|c|c|c|c|c|}
\hline No & Hypothesis & Direction & $\beta$ & Sig & Explanation \\
\hline 1 & $\begin{array}{l}\text { Availability positively influences the } \\
\text { willingness of customer participation in co- } \\
\text { creation activities }\end{array}$ & Positive & .199 & .000 & Supported \\
\hline 2 & $\begin{array}{l}\text { Privacy has a positive effect on the } \\
\text { willingness of customer participation in co- } \\
\text { creation activities }\end{array}$ & Positive & -.022 & .683 & Not Supported \\
\hline 3 & $\begin{array}{l}\text { Responsiveness has a positive effect on the } \\
\text { willingness of customer participation in co- } \\
\text { creation activities }\end{array}$ & Positive & .211 & .000 & Supported \\
\hline 4 & $\begin{array}{l}\text { Social Motivation has a positive effect on } \\
\text { the willingness of customer participation in } \\
\text { co-creation activities }\end{array}$ & Positive & .427 & .000 & Supported \\
\hline 5 & $\begin{array}{l}\text { Financial motivation has a positive effect } \\
\text { on the willingness of customer participation } \\
\text { in co-creation activities }\end{array}$ & Positive & -.001 & .987 & Not Supported \\
\hline
\end{tabular}

The third hypothesis is supported (beta value is .211 and significance value is .000), responsiveness has a positive effect on the willingness customers' participation in co-creation activities. This finding supports Chen's et al., (2011) study which states that responsiveness influences the level of participant contributions in co-creation activities, as well as the duration of participation in co-creation activities. The quality of responsiveness in online services is positively correlated with the level of web page visits. When service providers are able to interact well with customers, this encourages customers to continue to use the application or web page. It also triggers a sense of customer engagement with the company, which in turn will increase the level of willingness to participate in co-creation activities.

The fourth hypothesis is supported (beta value is .427 and a significance value is .000 ), therefore social motivation has a positive effect on the willingness of customers' participation in cocreation activities. These finding supports previous studies conducted by Varleye (2015) and Fuller (2010) which proves that the willingness of customers to participate in a co-creation program depends on the characteristics of the benefits expected by consumers. This finding also confirms that customers expect opportunities to improve the quality of social relationships when the relevant customers are willing to participate in joint creative activities (Nambisan, 2009).

The fifth hypothesis is not supported (beta value is -.001 and a significance value is .987). The result shows an opposite finding i.e. financial motivation has negative and no significant effect on the willingness of customers' participation in co-creation activities. This finding supports both Füller (2006) and Fernandes \& Remelhe (2016) studies which show that financial rewards proven has no effect on willingness of consumers to participate in joint creative activities. Differences in research contexts to be one of the reasons why the fifth hypothesis is not supported. Financial motivation to be a factor that drives customers to engage in co-creation activities. However, the finding in this study indicates that the desire to build a deeper relationship with a preferred brand is stronger cause than the value of its economic benefits (Martin, 2015). 


\section{Conclusions}

In summary, the five proposed factors that thought to have an influence on the willingness of customers' participation in joint creative activities, it turns out that only three factors are confirmed to be influential videlicet availability, responsiveness and social benefits. Two factors namely privacy and financial benefits are proven to have no effect.

Availability has an influence on consumers' willingness to participate in joint creative activities. The system and technical reliability of the application and online service pages influence the perception of ease of use of the customer. Customers will perceive positive attitude to online services, if their transactions are carried out smoothly (Mustak et al., 2013). This positive perception will have an impact with customer ratings on the hosting professionalism of online service companies. Professionalism in the form of technical fluency will affect customer assessment of other programs offered by the company, such as in co-creation activities in order to obtain ideas and improvements from customers.

Privacy has no influence on customers' willingness to participate in joint creative activities. Today's customers no longer consider privacy as the most important thing in assessing the quality of online services. For example, in banking transactions, customers already trust the security of online services that are used through the verification process repeatedly during the transaction process (Landrum, 2017). In addition, customers also tend to choose to secure personal data by using service providers that have been proven reliable (Alton, 2018). Customers actually do not know or aware of the conditions whether their personal data has been misused by the online services they use. Moreover, the ignorance level about fraud issues information subsequently does not cause excessive suspicion or over-concern by the customers.

Customers also have high trust in third parties such as the government. Regulations applied by the government are considered to be sufficient to secure online business. To be specific some condition like covering legal instruments, policies, independent regulation of the industry, technical standards and related law enforcement processes. These elements can create a positive environment and infrastructure to support better relationships between customers and online service providers (Velmurugan, 2009).

Responsiveness has a significant influence on consumers' willingness to participate in cocreation activities. Customers will positively evaluate companies that have high responsiveness through positive feedback through their experience when interacting on the web page. Customers who have a positive perception of the company will also rate it positively for other programs offered by the company, including the co-creation program.

Social Motivation has a significant influence on consumers' willingness to participate in cocreation activities. Social benefits become important things related to the desire to work, look for pleasant experiences, and the development of broader relations (Astafyeva \& Halliday, 2014).

Financial motivation does not have a significant effect on consumers' willingness to participate in joint creative activities. Consumers are no longer focused on financial matters alone, but rather on holistic benefits. For example in case co-creation program will contribute to the customer self-image conversely will the activities increase their knowledge, and whether it will give a chance to build social or business network. It can be inference that within this present case, financial compensation is seen as a mere bonus.

\section{Managerial Implications}

This study is expected to enrich the knowledge of marketers and companies by providing input and description that are crucially needed by online service providers to influence consumers willingness to participate in co-creative activities. The current marketing strategy must be re-developed and in its implementation should consider some more aspects so that it can reach millennial (and even to z 
generation consumers), who are current active and very large consumers (Astafyeva \& Halliday, 2014).

This study offers several managerial implications in several ways. First, the level of professionalism of online service providers in delivery of the services so far will affect customer motivation to participate in the co-creation programs offered. The co-creation program requires active customer participation with the support of the reliability of the page and application system that facilitates the process of contributing customer ideas to improve service quality. Interactive communication with customers is important, because they are always want a match between the product delivered by the service provider and their needs or desires. Thus the openness and responsiveness of online service providers in responding to customer aspirations and complaints becomes crucial which always needs to be pursued.

Second, service providers need to facilitate customers in obtaining social benefits such as are social relations, social status, and social rewards. Social benefits are achieved by providing facilities for the formation of a community of customers that facilitate the achievement of desired social values (Etgar, 2008), specifically the opportunity to connect with people who have similar thoughts and selfefficacy (Holbrook, 2006). The customer community forum also facilitates the process of idea between customers related to joint creative activities initiated by service providers.

\section{Limitations of the Study and Direction of Future Studies}

Lastly, limitation of the study should be acknowledged in order to provide opportunities to develop better future studies. The first limitation is the sampling design of this study tend to focus on young consumer generation with the majority profession as school students, college students and job seekers. Hence, the generalization of the findings obtained from this study should be implemented with caution or carefully to the wider population. Future studies can address this issue by involving more heterogeneous populations in order to increase the level of generalization.

The second limitation is the new research model which includes dimensions of online platform quality, social motivation and financial motivation. The research model can add other factors that underlie consumers' willingness to participate in co-creation activities from psychological aspects such as altruistic values, namely efforts to create benefits for others that encourage consumers to do creative activities together with people with similar interests, knowledge and skills (Holbrook, 2006). In other word, it is interesting to examine how the opportunity to form a community of co-creations is able to form a stronger sense of ownership, identity and bonds will increase wider benefits (Achrol \& Kotler, 2006). Accordingly, future studies could include the value of altruism as a third motivational factor besides social motivation and financial motivation so as to produce a more comprehensive perspective.

Qualitative studies are highly recommended to assess predictors of willingness to participate in creative activities together with consumers, thus this type of study will describe the opinions of respondents in more detail. As a unique and powerful influence group of consumers, millennial generation has widely discussed in depth but yet still not fully understood (Drake-Bridges and Burgess, 2010; Noble et al., 2009; Smith, 2012). Due to the fact, it might be important and relevant to examine consumers of millennial generation in future studies (Kotler \& Lee, 2016; Smith, 2012) and also $\mathrm{z}$ generation owing to their impingement in reshaping businesses pattern in the world.

\section{References}

Achrol, R. S., \& Kotler, P. (2014). The service-dominant logic for marketing: A critique. In Lusch, R. F. \& Vargo, S. L. (Eds) The service-dominant logic of marketing, (p. 338-352). Routledge.

Alton, Larry. (2018, June 14). The 4 Top Security Concerns on the Minds of Millenials. Retrieved from https://www.forbes.com/ 26 Desember 2017 
Astafyeva, S. V. \& Alexandra, H. (2014). Millennial cultural consumers: co-creating value through brand communities, Arts Marketing: An International Journal, 4(1/2), 119 - 135

Basoglu, N., Daim, T. \& Polat, E. (2014). Exploring adaptivity in service development: the case of mobile platforms. Journal of Product Innovation Management, 31(3), 501-515

Barrutia, J. M., \& Gilsanz, A. (2013). Electronic service quality and value: do consumer knowledgerelated resources matter? Journal of Service Research, 16(2), 231-246.

Carlson, J., \& O' Cass, A. (2010). Exploring the relationships between e-service quality, satisfaction, attitudes and behaviours in content-driven e-service web sites. Journal of services marketing, 24(2), 112-127.

Chen, Y., Fay, S., \& Wang, Q. (2011). The role of marketing in social media: How online consumer reviews evolve. Journal of interactive marketing, 25(2), 85-94.

Drake-Bridges, E., \& Burgess, B. (2010). Personal preferences of tween shoppers. Journal of Fashion Marketing and Management: An International Journal, 14(4), 624-633.

Elliott, M. T. \& Speck, P. S. (2005). Factors that affect attitude toward a retail web site. Journal of Marketing Theory and Practice, 13(1), 40-51

Elsharnouby, T. H., \& Mahrous, A. A. (2015). Customer participation in online co-creation experience: the role of e-service quality. Journal of Research in Interactive Marketing, 9(4), 313-336.

Elsharnouby, T. \& Parsons, E. (2010). A broader concept of relationships: Identifying new forms of consumer-provider interactions in Egyptian financial services. Journal of Marketing Management, 26(13), 1367-1388.

Elsharnouby, T., \& Parsons, E. (2013). When Relationship Marketing Goes Wrong: Opportunism and Consumer Well-Being in Consumer-Bank Relationships. Journal of Relationship Marketing, 12(2), 141-163.

Ernts, H., Hoyer, W. D., Krafft, M. and Soll, J. Henrik (2010). Consumer Idea Generation. Working Paper, Vallendar: WHU. Available at: https://www.scirp.org/(S(351jmbntvnsjt1 aadkposzje))/reference/ReferencesPapers.aspx?Ref erenceID $=1740259$

Etgar, M. (2008). A descriptive model of the consumer co-production process. Journal of the academy of marketing science, 36(1), 97-108.

Fernandes, T., \& Remelhe, P. (2016). How to engage customers in co-creation: customers' motivations for collaborative innovation. Journal of Strategic Marketing, 24(3-4), 311-326.

Filieri, R., \& Alguezaui, S. (2012). Extending the enterprise for improved innovation. Journal of Business Strategy, 33(3), 40-47.

Füller, J. (2006). Why consumers engage in virtual new product developments initiated by producers. ACR North American Advances.

Füller, J. (2010). Refining virtual co-creation from a consumer perspective. California management review, 52(2), 98-122.

Francis, J. E., Burgess, L., \& Lu, M. (2015). Hip to be cool: A Gen Y view of counterfeit luxury products. Journal of Brand Management, 22(7), 588-602.

Frey, K., Lüthje, C., \& Haag, S. (2011). Whom should firms attract to open innovation platforms? The role of knowledge diversity and motivation. Long Range Planning, 44(5-6), 397-420. 
Gera, R. (2011). Modelling e-service quality and its consequences in India: an SEM approach, Journal of Research in Interactive Marketing, 5(2/3), 203-225

Holbrook, M. B. (2006). Consumption experience, customer value, and subjective personal introspection: An illustrative photographic essay. Journal of business research, 59(6), 714725.

Hoyer, W. D., Chandy, R., Dorotic, M., Krafft, M., \& Singh, S. S. (2010). Consumer cocreation in new product development. Journal of service research, 13(3), 283-296.

Kim, J. H., \& Kim, C. (2010). E-service quality perceptions: a cross-cultural comparison of American and Korean consumers. Journal of Research in interactive Marketing, 4(3), 257-275.

Kim, M., Kim, J. H., \& Lennon, S. J. (2006). Online service attributes available on apparel retail web sites: an ES-QUAL approach. Managing Service Quality: An International Journal, 16(1), 51 77.

Korgaonkar, P.A. dan Karson, E.J. (2007). The influence of perceived product risk on consumers' etailer shopping preference, Journal of Business \& Psychology, 22(1), 55-64.

Kotler, P., \& Lee, N. (2016). Social marketing: Changing behaviors for good. Sage Publication.

Krishnamurthy, S. (2006). On the intrinsic and extrinsic motivation of free/libre/open source (FLOSS) developers. Knowledge, Technology \& Policy, 18(4), 17-39.

Landrum, Sarah. (2017, Juni 28). Millennials, Trust and Security. Retrieved from https://www.forbes.com/sites/ at $26^{\text {th }}$ Desember 2017

Lee, G. \& Lin, H. 2005. "Customer perceptions of e-service quality in online shopping", International Journal of Retail \& Distribution Management, Vol 33, No.2, 161-7

Loureiro, S. M. C. (2015). The role of website quality on PAD, attitude and intentions to visit and recommend island destination. International Journal of Tourism Research, 17(6), 545-554.

Mahrous, A. A. (2011). Antecedents of privacy concerns and their online actual purchase consequences: A cross-country comparison. International Journal of Electronic Marketing and Retailing, 4(4), 248-269.

Martin, E. J. (2015, Oktober 25). How to use authenticity, brands, and visuals to engage millennials. Retrieved from http://www.econtentmag.com/ at 15 Desember 2017

Montazemi, A. R., \& Qahri-Saremi, H. (2015). Factors affecting adoption of online banking: A metaanalytic structural equation modeling study. Information \& Management, 52(2), 210-226.

Moreno, F. M., Lafuente, J. G., Carreón, F. Á., \& Moreno, S. M. (2017). The characterization of the millennials and their buying behavior. International Journal of Marketing Studies, 9(5), 135144.

Mustak, M., Jaakkola, E., \& Halinen, A. (2013). Customer participation and value creation: a systematic review and research implications. Managing Service Quality: An International Journal, 23(4), 341-359.

Nambisan, S. (2002). Designing virtual customer environments for new product development: Toward a theory. Academy of Management review, 27(3), 392-413.

Nambisan, S., \& Baron, R. A. (2009). Virtual customer environments: testing a model of voluntary participation in value co-creation activities. Journal of product innovation management, 26(4), 388-406. 
Noble, S. M., Haytko, D. L., \& Phillips, J. (2009). What drives college-age Generation Y consumers?. Journal of business research, 62(6), 617-628.

O'Pappas, I., G. Pateli, A., N. Giannakos, M., \& Chrissikopoulos, V. (2014). Moderating effects of online shopping experience on customer satisfaction and repurchase intentions. International Journal of Retail \& Distribution Management, 42(3), 187-204.

Orozpe, N. (2014). Millenialsserán los consumidores del 2017.

Prahalad, C. K., \& Ramaswamy, V. (2004). Co-creating unique value with customers. Strategy \& leadership, 32(3), 4-9.

Ramaswamy, V. (2009). Leading the transformation to co-creation of value. Strategy \& Leadership, 37(2), 32-37.

Roberts, D., Hughes, M., \& Kertbo, K. (2014). Exploring consumers' motivations to engage in innovation through co-creation activities. European Journal of Marketing, 48(1/2), 147-169.

Santos, J. (2003). E-service quality: a model of virtual service quality dimensions. Managing Service Quality: An International Journal, 13(3), 233-246.

Schooley, C., Moore, C., Driver, E., Orlov, L. M., Ragsdale, J., \& Fossner, L. (2005). Get ready: the millennials are coming. Forrester Research: Changing Workforce series, 5.

Sheng, T., \& Liu, C. (2010). An empirical study on the effect of e-service quality on online customer satisfaction and loyalty. Nankai business review international, 1(3), 273-283.

Smith, K.T. (2012). Longitudinal study of digital marketing strategies targeting millennials. The Journal of Consumer Marketing, 29(2), 86-92

Tapscott, D. and Williams, A.D. (2006). Wikinomics: How Mass Collaboration Changes Everything. NewYork: Portfolio.

Van Noort, G., Kerkhof, P., dan Fennis, B. M. (2008). The persuasiveness of online safety cues: The impact of prevention focus compatibility of Web content on consumers' risk perceptions, attitudes, and intentions. Journal of Interactive Marketing, 22(4), 58-72

Vargo, S. L., \& Lusch, R. F. (2008). Service-dominant logic: continuing the evolution. Journal of the Academy of marketing Science, 36(1), 1-10.

Velmurugan, M. S. (2009). Security and Trust in e-Business: Problems and Prospects. International journal of electronic business management, 7(3), 151-158.

Verleye, K. (2015). The co-creation experience from the customer perspective: its measurement and determinants. Journal of Service Management, 26(2), 321-342

Veit, D., Clemons, E., Benlian, A., Buxmann, P., Hess, T., Kundisch, D. \& Spann, M. (2014). Business models. Business \& Information Systems Engineering, 6(1), 45-53.

Wirtz, J., Den Ambtman, A., Bloemer, J., Horváth, C., Ramaseshan, B., Van De Klundert, J., \& Kandampully, J. (2013). Managing brands and customer engagement in online brand communities. Journal of service Management, 24(3), 223-244.

Wolfinbarger, M., \& Gilly, M. C. (2003). eTailQ: dimensionalizing, measuring and predicting etail quality. Journal of retailing, 79(3), 183-198.

Wu, C. H. J.(2011). A re-examination of the antecedents and impact of customer partic-ipation in service. The Service Industries Journal, 31(6), 863-876 
Yang, Z. \& Fang, X. (2004). Online service quality dimensions and their relationships with satisfaction: a content analysis of customer review of securities brokerage services, International Journal of Service Industry Management, 15(3), 302-326

Yang, Z., \& Jun, M. (2002). Consumer perception of e-service quality: from internet purchaser and non-purchaser perspectives. Journal of Business strategies, 19(1), 19

Yen, C. H., \& Lu, H. P. (2008). Effects of e-service quality on loyalty intention: an empirical study in online auction. Managing Service Quality: An International Journal, 18(2), 127-146.

Zhang, X., \& Chen, R. (2008). Examining the mechanism of the value co-creation with customers. International Journal of Production Economics, 116(2), 242-250. 